\title{
The State of Research on Effectiveness and Equity (2Es) in Forests Management Regimes in Cameroon and Its Relevance for REDD+
}

\author{
Eugene Loh Chia ${ }^{1}$, Anne Marie Tiani ${ }^{1} \&$ Denis J. Sonwa ${ }^{1}$ \\ ${ }^{1}$ Center for International Forestry Research, Central Africa Regional Office, Yaounde, Cameroon. \\ Correspondence: Eugene Loh Chia, CIFOR-CARO, P. O. Box 2008, Messa Yaounde, Cameroon. E-mail: \\ e.chia@cgiar.org
}

Received: May 31, 2013 Accepted: September 29, 2013 Online Published: October 18, 2013

doi: 10.5539/enrr.v3n4p92 URL: http://dx.doi.org/10.5539/enrr.v3n4p92

\begin{abstract}
The process of designing and implementing the Reducing Emissions from Deforestation and Forest Degradation $(\mathrm{REDD}+)$ mechanism is gaining grounds in many tropical forest countries. There are concerns on the potentials of the existing forest management regimes to provide the necessary conditions for a successful REDD+ mechanism. This paper narrows this debate to Cameroon and examines past research on two forest regimes community forests and state forests regimes. It examines findings on equity in benefit sharing and the effectiveness of regimes to maintain or increase forest cover, and assess their compatibility with REDD+ exigencies. The paper argues that: (1) it is too early to draw conclusions on a suitable regime for REDD+ in Cameroon. 13, out of 14 research papers published up to 2011 accentuate on equity in benefit sharing, and the two regimes show proof of limited guarantee for the much expected REDD+ safeguards, this includes failures in vertical and horizontal distribution of benefits; (2) there is deficiency in studies on effectiveness of the forest regimes in managing forest cover as indicated by only 3 of the 14 studies. Despite the shortcomings in practice, certain elements of the forest legislation in Cameroon offer better opportunities for REDD+. This paper recommends more in-depth research based on rigorous methodologies to provide better bases for practitioners and policy makers to draw lessons from the management outcomes of the different regimes, which is relevant for the design of the national REDD+ policy strategy in Cameroon.
\end{abstract}

Keywords: research gap, tropical forests, benefit sharing, effectiveness, REDD+, Cameroon

\section{Introduction}

Reducing Emissions from Deforestation and Forest Degradation (REDD+) is the recent mitigation mechanism dominating forest policy debates in tropical forest countries. Despite being a global initiative, recent efforts on REDD+ have now been directed towards national and local levels with many tropical forests countries developing and engaging in both national level policy design and implementation, in addition to pilot REDD+ projects, through the support of multilateral and bilateral partners. Researchers (Angelsen, 2008; Angelsen et al., 2009, 2012) have made earlier attempts to direct the successful design and implementation of REDD+ mechanisms. Attempts have provided answers to burning questions such as: the type of institutional arrangements required in constructing a REDD+ framework and the type of policy reforms required to implement REDD+. Most of the responses provided were weighted against the climate effectiveness, efficiency and equity outcomes and their potentials to produce co-benefits (biodiversity conservation, poverty reduction and sustainable livelihoods, governance and secured rights).

This paper is about the context of REDD+ effectiveness and equity (2Es), which is important to understand the management regime that provides a better opportunity for a potential REDD+ mechanism in Cameroon. The paper assumes that management results from community and state managed forest regimes can provide lessons for the present REDD+ national strategy construction process. It analyzes the state of research by synthesising papers on the functioning and outcome of state and community forest regimes for the past decade. First, in the context of state managed forests, the paper verifies results reported on the effectiveness of the state to supervise forest cover change in production forest and more precisely in Forest Management Units (FMUs) (logging concessions) and equity in benefit sharing procedures of Annual Forest Fees (AFF). Second, the paper verifies results on forest cover change in community forests and benefit sharing of community forest exploitation revenues. Lastly, the paper contextualises the findings with the present REDD+ process. It is a discussion 
relevant for the REDD+ process in Cameroon and the outcome of this analysis is also important for the other Congo Basin countries.

Lessons learned from previous payments for ecosystem services including the first generation REDD+ projects have opened and shaped global and national level debates on the social, ecological and governance issues surrounding the future of REDD+. Some relevant scholarships for learning include:

1) Social safeguards and co-benefits in REDD+ (Chhatre et al., 2012; Jagger, et al., 2012; Visseren-Hamakers et al., 2012; Richards \& Panfil, 2011);

2) Lessons for effectiveness and efficiency in measuring, verifying and reporting forest cover and carbon stocks (Gupta et al., 2012; Palmer Fry, 2011; Maniatis \& Mollicone, 2010; Asner, 2011; Herold \& Skutsch, 2011);

3) Lessons for REDD+ governance and tenure (Visseren-Hamakers et al., 2012; Corbera \& Schroeder, 2011; Murdiyarso et al., 2012; Gupta, 2012; Larson \& Petkova, 2011; Awono et al., 2013; Larson et al., 2013);

4) Lessons for leakage and permanence in REDD+ (Atmadja \&Verchot, 2011; Brown et al., 2000; Lasco et al., 2007; Murray et al., 2004);

5) Equality concerns in REDD+ (Börner et al., 2010; McDermott et al., 2012; Corbera et al., 2007b; Murdiyarso et al., 2012).

Nonetheless, the context and scale specificities of REDD+ design and implementation related to effectiveness and equity, leave many questions unanswered across countries engaging in REDD+. This is due to the differences in the design and implementation of governance structures in the management of forests and forests related sectors.

Cameroon is an important country for REDD+ (Somorin et al., 2013). It is one of the countries sharing the trans-boundary Congo basin forests which is second to the Amazon in carbon stock quantity containing about 56 741 million tonnes of forests carbon (Molua, 2012; Food and Agriculture Organisation (FAO), 2011). Sustainable forest management including afforestation and reforestation have the potential to conserve and increase carbon stocks, while deforestation, degradation and poor forests management increase(s) carbon emissions (Molua, 2012). According to the Cameroon Readiness Preparation Proposal (R-PP), drivers of deforestation include agriculture, illegal logging, industrial logging, mining, infrastructure and demographic pressure (MINEPDED, 2012). Epule et al. (2011) also used statistical models to demonstrate that population growth is the major driver of deforestation in Cameroon, followed by agriculture-arable production and permanent crop land, although illegal logging activities were not taken into account and might be responsible for annual change rates (-1.07 between 2005 and 2010) in the forest cover (Reboredo, 2013a). Moreover, Lawson \&MacFaul (2010) concluded that despite considerable reductions in deforestation rates illegal logging represents between $22 \%$ and $35 \%$ in Cameroon.

The REDD+ process in Cameroon is led by the government through the Ministry of Environment, Nature Protection and Sustainable Development (MINEPDED), with technical and financial support from bilateral, multilateral organizations and non-governmental organizations. In Cameroon, as in other forested tropical countries that engage in REDD+, despite progress made in preparing the implementation of the R-PP and the designing of the national REDD+ strategy, so many questions still remain unanswered in terms of effectiveness and equity relating to Measurement Reporting and Verification (MRV), safeguards (governance, benefit sharing, poverty reduction and biodiversity). Providing answers to these questions - demand that barriers such as the multi-sectoral and multi-stakeholder nature of REDD+ be overcome and this further requires efficient collaboration, partnership and adequate institutional capacity (Somorin et al., 2013; Brown et al., 2011). In 2012, the R-PP of Cameroon was validated and an official partnership status with the United Nations collaborative program on REDD+ (UN-REDD) was accorded. The country is, thus, expected to benefit from the UN-REDD financial and technical support to national programmes, therefore, a clear vision for a national approach for REDD+ is crucial, taking into consideration existing challenges and opportunities of forest management regimes.

\section{An Overview of Forest Resource Regimes in Cameroon}

Forest management before the 1990s in Cameroon was characterized by a centralized system of management with the state having legal and hegemonic control over forest land with the rights of communities limited to user rights (Oyono et al., 2005; Oyono, 2005). Failures of the state authoritarian policies - injustice, marginalization, inequality, increase conflicts between stakeholders; declining contribution of forest sector to national economy and development; and growing threats to biodiversity (Assembe, 2006b; Ekoko, 1997, 2000), ushered in the 1990 forest policy reforms. The reform process lead to the 1994 forest law by presidential Decree No. 94/01 of 
20th January 1994 and its decree of implementation No. 95/531/PM of August 1995 (GOC, 1994 \& 1995). This reform was aimed at promoting community participation in forest management; contribute to poverty reduction and the sustainable management of forests resources and biodiversity conservation (Oyono, 2007; Minang, 2007) The new forest law divided the National Forest Estate (NFE) into Permanent and Non-Permanent Forest Estates with different management entities (Tables 1 \& 2). The Production forest, precisely FMUs is the unit of study for state forest management, because it represents the largest surface area open for exploitation, and secondly, it is the entity that generates the greater share of forest revenues. Despite not being managed directly by the state, this paper assumes production forest as state managed forest because the state has responsibility to collect and distribute production forest exploitation revenues and also supervises forest cover change in production forest.

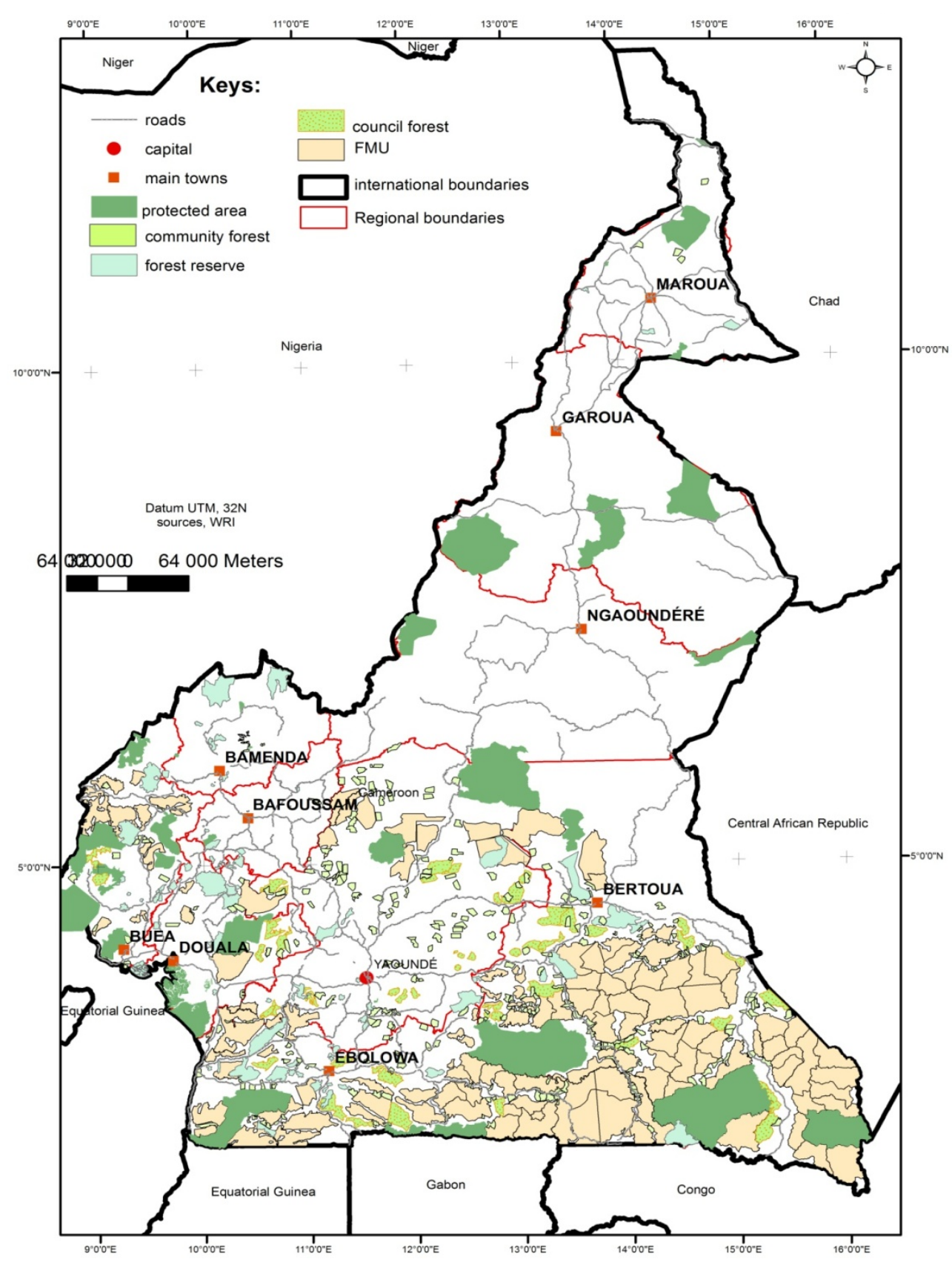

Figure 1. Map showing distribution of forests types in Cameroon (WRI, 2011) 


\subsection{The Permanent Forests Estate (PFE)}

The PFE is made up of production forests (FMUs, Forest Reserves), protected areas (national parks, wildlife reserves, sanctuaries and hunting zones) and council forests (GOC, 1994) (Table 1). Forest cover in the PFE is made up of $66 \%$ dense forest, $11 \%$ of mixed forest and $23 \%$ of less dominant forest vegetation areas (WRI, 2011).

Table 1. Distribution of forest cover between forest management entities in the PFE in 2011

\begin{tabular}{cccc}
\hline Forest Category & No & GIS area (ha) & \% of NFE \\
\hline Production forests & 186 & $8,108,821$ & 46 \\
Protected areas & 86 & $7,397,581$ & 42 \\
Council forests & 34 & 827,285 & 6 \\
Total PFE & & $16,333,687$ & 94 \\
\hline
\end{tabular}

Source: WRI 2011.

The state through the Ministry of Forestry and Wildlife (MINFOF) is responsible for directing and managing all forest types in Cameroon with a mandate to ensure sustainable forest management and the distribution of benefits emanating from the exploitation of forest resources. According to Decree No. 95/53/PM of August 23 1995, production forests are areas located for sustainable and sustained harvesting of timber and other forests related products. The FMUs created in 1994, constitute the largest allocation of the production forests with areas not exceeding 200,000 ha allocated to timber exploitation companies for a period of 15 years through a bidding process upon submission and approval of a management plan (GOC, 1994 \& 1995). However, companies can occupy one or more FMUs constituting forest concessions. Logging companies are required to map out the envisioned annual harvestable areas for the entire planned logging rotation in a given FMU. Furthermore, logging companies are also obliged to submit before the start of each year, an official annual harvestable area note detailing area, volume and the species to be harvested to MINFOF (WRI, 2011), to facilitate the monitoring of effective logging in forest concessions. Forest management plans were instituted as safeguards for the sustainable management of production forests (Cerutti et al., 2008). Concessions are viewed as a means of delivering services of public and collective interests through the association of private investment and public regulation (Karsenty et al., 2008).

According to the 1994 forest legislation, income generated as Annual Forest Fees (AFF) through access and exploitation rights is shared between the state, councils and communities living adjacent to forest exploitation units. The legislation stipulates that $10 \%$ of the $50 \%$ that goes to the councils where logging activities are carried out is allocated to the villages accommodating the logging companies (Oyono, 2005; Alemagi \& Kozak, 2010). Fees were previously allocated in cash but they are presently allocated through community development projects (GOC, 1994, 1995; Cerutti et al., 2010).

\subsection{Non-Permanent Forest Estate (NPFE)}

The NPFE is made up of unclassified forests, community forests and private forests (Table 2). Community forest management regime in Cameroon emerged from the 1994 forest legislation and its accompanying decrees and circulars (GOC, 1995 \& 1994). The decentralized forest management regime approach was aimed at promoting community participation in sustainable forest management and poverty reduction. This approach allowed communities to create a forest in the NPFE with a management plan agreed upon between communities and the forestry administration. Presently, community forests occupy about 6\% of the NFE (WRI, 2011) and establishing a community forest is possible only in areas where communities have customary rights (Oyono et al., 2007) with the area not exceeding 5000 ha. The legislation further stipulates that village communities postulating for community forest must organize themselves into legal entities such as common initiative groups, associations or cooperatives (GOC, 1995). According to the community forest management unit of MINFOF, the creation of community forests involves: (i) public awareness and information campaigns at the level of the village; (ii) formation of a management entity; (iii) delimitation of future community forest; (iv) designation of community forest; (v) development of a simple management plan (vi) the approval of the simple management plan (v) and the signing of the management agreement. Once the management plan is signed, communities can commence management and exploitation with benefit flows going directly to the community. The management plan is to 
ensure that communities maintain healthy forest(s) ecology through forest regeneration and conservation (MINFOF, 2009).

Table 2. Distribution of forest cover between forest management entities in the NPFE in 2011

\begin{tabular}{llll}
\hline Category of forest & No & GIS area (ha) & \% of NFE \\
\hline Community forests with provisional management plan & 14 & 50,036 & - \\
Community forests with simple management plan & 103 & 276,333 & 2 \\
Community forests with final management plan & 184 & 689,167 & 4 \\
Sub total & 301 & $1,015,536$ & 6 \\
Sales of standing volume & 49 & 114,042 & - \\
Total NPFE & - & $1,129,578$ & 6 \\
\hline
\end{tabular}

Source: WRI 2011

The management agreement is signed for 5 years renewable over a period of 25 years and it is liable to suspension by the state if management is contrary to the agreed management plan (GOC, 1995). Community forest management regimes have existed for more than a decade in Cameroon and as one of the objectives of this paper, we seek to verify whether enough research has demonstrated the effectiveness of community forest management in terms of managing and maintaining forest cover and equality in benefit sharing.

\section{Study Approach and Methods}

\subsection{Study Approach}

The study is based on the effectiveness and equity framework. The 2Es + have been widely used in assessing the design and implementation of decision making and different policy interventions from the local, national and international levels. The outcome of these assessments has contributed in policy design in the different domains. Some authors have used this framework to assess governance and institutional processes in environmental decision making. It has also drawn much attention in climate change policy design and implementation (Füssel, 2007; Tol, 2001; Ikeme, 2003; Grasso, 2007). Research in forest ecosystem management has extensively used this framework in assessing successes and failures (Agrawal \& Angelsen, 2009; Nebel et al., 2005; Corbera et al., 2007a, 2007b). This paper employs a direct and simple definition of the 2Es. Effectiveness depicts the capacity of a management system to actually maintain or increase forest cover and the ability of that system to ensure permanence. It also involves how the system influences motivation and its degree of exposure to corruption (Vatn et al., 2011). REDD+ payments depend on the ability of individuals, communities and countries to effectively reduce emissions through forest cover management. The ability of systems to keep forest standing is described as carbon effectiveness and in a typical REDD+ carbon effectiveness scenario, forest cover needs to be kept standing for a long period of time (Angelsen, 2008).

Literature on equity identifies two types - procedural equity and distributional equity. Procedural equity deals with decision making issues and distributional equity which this paper is limited to, addresses the distribution of benefits (McDermott et al., 2012). Distributional equity describes the distributional effects of a system (Vatn et al., 2011) and in this paper we identify production forests controlled by the state whose management have been tailored to logging companies (private sector) and community forest management as the systems, looking at how the distribution of benefits (financial gains from forest exploitation) have been working within these systems. It also explains the fair distribution of benefits to land use actors and the probable effects of management strategies on local and indigenous communities (Angelsen \& Wertz-Kanounnikoff, 2008). Benefit sharing options include sharing between the state, regional, local governments and communities (vertical) and between communities, within communities and/or between households in a community (horizontal) (Pham et al., 2013). In a typical REDD+ equity scenario, forest management systems need to ensure that REDD+ payments and co-benefits are distributed in an equitable manner which benefits the poor (Angelsen, 2008).

\subsection{Methods}

This paper examines studies on forests under state management and forests under community management to identify existing knowledge on forest cover management and equity in benefit sharing, which enabled us to see how research is needed to respond to emerging REDD+ implementation questions. The search for literature 
followed author names and key words (e.g. decentralized forest management in Cameroon, community forest management, distribution of annual forest fees, corruption and governance in forest management in Cameroon, logging concessions and deforestation, benefit sharing etc) in Google, Google scholar and Web of Science. A huge number of studies were found, but only 14 peer review articles and working papers were relevant for the study (Table 3). Selection of the 14 papers was based on four conditions. First, research should fall between 2001 and 2012. This is the period that reveals the implementation of the 1994 forest legislation. Secondly, research should be original in nature. Thirdly, the research must highlight benefit sharing either in community forest management or the distribution of forest revenues by the state. Lastly, it was limited to research presenting results on the management of forest cover in both state and community managed forests.

For state managed forests, we restricted our observation to studies related to Forest Management Units (precisely logging concessions) looking at their ability to maintain or increase forests cover and equity in benefit sharing (vis-à-vis) the state and forest communities in and around logging concessions. Community forest examination was limited to studies on community's ability to maintain forest cover and benefit sharing within community forests. In each of the 14 studies, we examined particularly the methods employed in the study, findings and conclusions.

\section{Results}

Table 3, shows the different studies and their conclusions regarding benefit sharing through the centralized forest management and community forest management systems, and the effectiveness of the management systems to maintain or increase forest cover. Most of the research employed a narrative approach in their studies and in the framework of the 2Es, equity in benefit sharing dominated research for the past decade (i.e. 12 of the 14 studies), as opposed to research on forest cover change (3 of the 14 studies) and vulnerability of management systems to corruption (9 of the 14 studies).

Table 3. Studies on the outcome of management systems on 2Es

\begin{tabular}{|c|c|c|c|c|c|c|c|}
\hline Author/Year & $\begin{array}{l}\text { Analytical } \\
\text { tool }\end{array}$ & $\begin{array}{l}\text { Corruption } \\
\text { in SM }\end{array}$ & $\begin{array}{l}\text { Corruption } \\
\text { in CFM }\end{array}$ & $\begin{array}{c}\text { Forests } \\
\text { cover SM }\end{array}$ & $\begin{array}{c}\text { Forests } \\
\text { cover } \\
\text { CFM }\end{array}$ & $\begin{array}{c}\text { Benefit } \\
\text { sharing } \\
\text { SM }\end{array}$ & $\begin{array}{c}\text { Benefit } \\
\text { sharing } \\
\text { CFM }\end{array}$ \\
\hline Mertens et al., & Econometric & & & - & & & \\
\hline 2001 & model & & & + & & & \\
\hline Begombe, 2003 & Narrative & & - & & & - & - \\
\hline Oyono, 2004 & Narrative & & - & & & & - \\
\hline Oyono, 2005 & Narrative & & & & - & & - \\
\hline $\begin{array}{l}\text { Oyono et al., } \\
2005\end{array}$ & Narrative & & & & & - & \\
\hline Assembe, 2006a & Narrative & & & & & & - \\
\hline Assembe, 2006b & Narrative & & & & & & - \\
\hline $\begin{array}{c}\text { Cerruti and } \\
\text { Tacconi, } 2006\end{array}$ & Narrative & - & & & & & \\
\hline $\begin{array}{c}\text { Oyono et al., } \\
2006\end{array}$ & Narrative & & & & & & $\begin{array}{l}+ \\
-\end{array}$ \\
\hline $\begin{array}{c}\text { Cerutti et al., } \\
2008\end{array}$ & Narrative & & & - & & & \\
\hline Lescuyer, 2008 & Narrative & & & & & - & - \\
\hline $\begin{array}{c}\text { Oyono et al., } \\
2009\end{array}$ & Narrative & - & & & & - & \\
\hline $\begin{array}{c}\text { Cerutti et al., } \\
2010\end{array}$ & Narrative & & & & & - & \\
\hline $\begin{array}{l}\text { Ezzine de Blas, } \\
2011\end{array}$ & Narrative & & & & & & - \\
\hline
\end{tabular}




\subsection{Distribution of Annual Forest Fees by the State}

The AFF is an area based forestry tax introduced as part of the 1994 Forest Law, with the objective to increase tax revenues and promote sustainable forest management. Revenue sharing was driven by a response to external pressure, tension and conflicts between communities and local councils on the one hand, and logging companies and the state on the other hand. Thus, AFF also had as objective to ameliorate local economic development, poverty reduction and conflict abatement in and around communities' adjacent logging concessions and the state (Morrison et al., 2009).

The findings of 5 of the 14 studies emphasise that benefit sharing process through the state is characterized by corruption, lack of transparency, lack of responsible management practices and proper safeguards for revenues allocated for rural development, poverty alleviation and livelihood support systems which is not a surprise when analysing the Index of Economic Freedom and Corruption Perception Index in Cameroon (Reboredo, 2013b). There is inconsistency between the amount of the AFF allocated to councils and communities declared at the central level and the amount which is actually received by councils and communities. In Mindourou local council area (East region) for example data from the state in 2004 indicated a transfer of 578 million CFA as the $40 \%$ allocated to the council, while the council acknowledged a transfer reported at 544 million CFA. Similar findings were reported in Gari Gombo Local Council area where the council acknowledged receiving 230 million CFA as opposed to 321 million CFA declared at the central level (Oyono et al., 2009). Oyono et al. (2009) further reported differences in the $10 \%$ AFF allocated to the villages around the Mindourou council area and noted that the amount spent on village development activities is far less than the amount supposedly allocated. Begombe (2003) also reported mismanagement and misappropriation of AFF in councils and villages in the Dimako and Yokadouma Sub-Division in the East Region. Cerutti et al. (2010) also reported embezzlement, mismanagement and governance failures in the distribution of AFF. Another study across nine communities in the forest belt of Cameroon, indicate that a considerable part of the AFF do not reach communities (Lescuyer et al., 2008). Another study in villages (Akok, Kaya and Koli Ngoumou) in the forest zone of Cameroon showed that the circulation of forest fees is characterised by inequality as the benefits are more profitable to 'forestry elites' than to local communities (Oyono et al., 2005).

\subsection{Forest Cover Change in FMUs - Logging Concessions}

For the past decade, very limited studies have presented findings on forest cover change in logging concessions. Results from logging concessions in the East region of Cameroon, indicate that logging activities induce forest cover change and in some parts of the study area, forest cover change increases with the value of forest rent (Mertens et al., 2001). Despite not related to logging concessions, studies using statistic models and remote sensing have reported interesting results on deforestation in Cameroon (Epule et al., 2011; Djoufack et al., 2103).

According to Cerutti et al. (2008), in 2006, about 68\% of timber production in FMUs marginalized the improved harvesting system put in place by the 1994 forestry legal framework. The study concluded that the submission of management plans by logging entities is not a proof for improved forest management. However, the study was limited to a number of species rather than an overall evaluation of forest cover change within logging concessions. Two of the studies highlighted corruption malpractices in centralized forest management regarding the award of concessions (Oyono et al., 2009; Cerutti \& Tacconi, 2006). One of the studies reported irregularities and corruption in the allocation of forest concessions and other timber exploitation titles and concluded that logging concessions acquired through corruption malpractices are vulnerable to unsustainable timber harvesting and deforestation (Cerutti \& Tacconi, 2006).

\subsection{Benefit Sharing and Forest Cover Change in Community Forests}

Findings in benefit sharing in community forests were presented in 9 out of of the 14 studies (Table 3). Community forest revenues are generated through the exploitation of forest products with the responsibility of the community forest management committees to ensure equitable distribution. The key findings indicate that the distribution of parafiscal and community forests' revenues is surrounded by corruption, lack of accountability, transparency, elite capture and confiscation of community forest revenues and parafiscal compensations. It stresses that many community forests appears to belong to external elites and village chiefs (Oyono, 2005; Begombe, 2003). The aspect of elite capture and domination by village chiefs in benefit sharing was reported by other studies in parts of the South, East and North West Regions of Cameroon (Oyono, 2004). Similar studies indicate that most of community forest net benefits are distributed among specific actors and interest groups and only a small percent invested in collective community development (Ezzine de Blas et al., 2011). Some authors highlight inequalities in the distribution of financial revenues from logging operations in some community forests with a great share allocated to one ethnic group (Bantus) than the other (Baka-Pygmies) (Assembe, 
2006a). In the Kongo community forest area in the East Region, Assembe (2006b) also reported inequality in the distribution of community forest revenues. On the other hand, other studies indicate that some community forests show positive governance outcomes in the management of community forests' revenues and parafiscal compensations (Oyono et al., 2006). Six of the studies, present findings that reveal corrupt practices in community forests management (Table 3).

Limited studies have reported the impact of community management on forest cover change in community managed forests. The study by Oyono (2004) and Oyono et al., (2005) indicate that institutional and governance failures in community forest management resulted to forest ecosystem degradation. However, the study is based on broad theoretical assumptions and.lacks enough demonstration to support its findings,

\section{Discussion}

The construction of the REDD+ mechanism is raising so much concern about its ability to promote sustainability goals such as biodiversity conservation, sustainable use of forests and better livelihoods for local communities and indigenous people (Chhatre et al., 2012). To respond to these concerns, different carbon conservation initiatives are designing 'safeguards' to avoid harm to ecosystem values and local communities (Visseren-Hamakers et al., 2012). In addition to the safeguards of the United Nations Framework Conventions on Climate Change (UNFCCC), other REDD+ initiatives are designing their own safeguards, such as the World Bank Forests Carbon Partnership Facility (FCPF), UN-REDD and other carbon certification schemes (Visseren-Hamakers et al., 2012). However, all the initiatives stress a need for broader environmental and social issues in the design and implementation of REDD+ such as better livelihoods, poverty reduction, governance and rights of local communities. The social dimensions of equity are relevant for social safeguards (Visseren-Hamakers et al., 2012) which agree with the Triple Bottom Line concept (TBL) of Elkington (1997) where sustainability must be assured by both social and environmental responsibilities of governments and businesses. Furthermore, the three P's of the TBL concept (people, planet and profit) are not antagonistic - they might combine and be the goal of governments, enterprises and non-profit organizations (Reboredo, 2013b).

State management of forests in Cameroon, depict centralized forest management. Centralized forests management can protect forest and enhance re-growth, though it requires expensive implementation. According to Karsenty (2008), state forests' management through logging concessions can promote sustainable forests management if accompanied by specific measures. Furthermore, centralized approach to REDD+ is relevant to handle leakage, guarantee permanence, and provide reliable monitoring, reporting and verification (Phelps et al., 2010). Critics of centralized forests' management highlight that based on previous management results, centralized forest management will not be able to deliver for REDD+, unless issues such as tenure, benefit sharing and local engagement are seriously taken into consideration (Phelps et al., 2010). According to other scholars, community forests' management schemes have the potentials of avoiding deforestation and the restoration of forest cover and forest density. They also provide avenues for reducing forest carbon emissions and sustainable rural development (Klooster \& Masera, 2000). Success stories from decades of community forests' management can provide insights for better REDD+ design and implementation because of greater community participation and buy-in, which increases the 2Es (Agrawal \& Angelsen, 2009) .

\subsection{Forest Regimes and Equity in Benefit Sharing}

Matching these positions to the Cameroon experience and drawing on existing studies identified by this paper, it shows that centralized forest management and community forest management systems offer limited opportunities for REDD+, as they marginalize the social safeguards related to equity in benefit sharing. However, on paper, the forest legislation demonstrates rational mechanisms for distributing AFF and revenues in community forest. The distributional equity findings in centralized forest management indicate flaws which do not fit the present REDD+ prerequisites because financial flows from REDD+ might not reach communities leading to limited social benefits. The State is failing in its responsibilities to distribute equitably the AFF generated from forest logging concessions to local governments and communities. In the context of REDD+, such a scenario can possibly fuel non-permanence. Larson (2011) affirms that equity issues are liable to isolate forest based communities, which might increase conflicts and undermine forest carbon emission reductions.

On the other hand, community forests as well do not provide suitable atmosphere for social benefits and poverty reduction. The domination of local chiefs and external elites, signify that chiefs and other lead factions in communities might engage in carbon deals without proper benefit sharing for communities. Limited benefits for communities are a disincentive for household participation in initiatives such as carbon conservation. In Nepal for example, the willingness of the communities to participate in conservation schemes is driven by the pay-back they receive. A substantial share of financial flow from the exploitation of their community forest is spent on 
community education and health infrastructure (Murdiyarso \& Skutsch, 2006). In the humid forest zone of Cameroon, the willingness of communities to participate and engage in carbon conservation initiatives is determined by factors linked directly and indirectly to their livelihood and poverty reduction strategies (Chia et al., 2013).

Despite the failures identified in the sharing of forest exploitation benefits, there exist institutional mechanisms to guarantee the equitable distribution of revenues geared towards poverty reduction and rural development, reduced inequality, conflict abatement and better participation. The AFF revenue collection and sharing system were put in place by the 1994 forest legislation to make certain the equitable distribution of forest revenues (GoC, 1994). In this light, with proper implementation, monitoring and the safeguarding of these approaches, the vertical benefit sharing exigencies of REDD+ can be achieved. Morrison et al. (2009) provided recommendations for improving the AFF revenue sharing system's capacity to achieve the poverty reduction objectives of forest management. These recommendations which are relevant for constructing and implementing a REDD+ benefit sharing mechanism includes: (i) the allocation of human and financial resources to build and ensure efficient, transparent, monitoring, local participation and accountability mechanisms as well as capacity building at all levels to implement these mechanisms; (ii) the involvement of actors such as civil society organisations and the legislative arm of the government as an ombudsman for villages with complaints of AFF mismanagement, investigate and sanction the misuse of AFF funds at the council and village levels (Morrison et al., 2009; Epule et al., 2013).

For the case of benefit sharing between communities and in communities, the legislation has as objectives to enhance community participation both in terms of management and the sharing of benefits (Oyono et al., 2007). In this context, measures are required to monitor and ensure the implementation of the social objectives of community forest simple management plans regarding participation, poverty reduction and community development. This is pertinent for ensuring permanence and carbon effectiveness in community level REDD+ initiatives.

\subsection{Carbon Effectiveness in Forest Regimes}

The design and implementation of REDD+ is not limited to social safeguards. It has a carbon conservation component through forest cover management. Very limited research in Cameroon has demonstrated the outcome of forest cover management in both centralized forest management and community forest management. This makes it difficult to assess the implication of forest management experiences for the design and implementation of REDD+. Theoretically, decentralized forest models have potentials of conserving forests; however, the experience of governance constraints in tropical forest countries makes the successful implementation of these models for effective forest conservation difficult (Tacconi, 2007). Research in different forest countries has shown that selective and sustainable logging has limited impacts on forest cover and biodiversity conservation (Putz et al., 2012; Gibson et al., 2011). The implementation of reduced impact logging techniques has produced mixed results, and some have been described to influence topography and the landscape characteristics (Putz et al., 2008). In Northwest Gabon, the assessment of the consequences of reduced impact logging indicates that with well designed harvest planning, worker training and low logging intensities, substantial carbon stocks and tree species can be preserved (Medjibe et al., 2011). The lessons on methods employed to carry out these studies can be replicated in Cameroon and other parts of the Congo Basin area in general. Research results from the recent Centre for International Forestry Research - FORAFAMA project will strengthen scientific evidence on the impact of logging activities on forest carbon which is relevant if REDD+ is to be implemented properly. The project assumes that logging concessions can be an integral part of REDD+, and assesses forest cover change in logging concessions and comparing them with other types of land management such as protected areas, community forests and unclassified forests.

Another important challenge of centralized forest management in the context of effectiveness in managing forest cover is corruption. Bribery during the award of logging concessions, contributes to degradation by increasing logging cost, thus, pushing logging companies to overharvest in order to recover the cost of bribes (Richards et al., 2003). This is a snapshot of centralized forest management in Cameroon as reported by Cerruti et al. (2008) in which logging titles were not awarded to the most technically competent logging companies.

Regardless of the limited research on forest cover change which is relevant for carbon effectiveness, the 1994 forest law had as objective to enhance biodiversity conservation and sustainable forests management (Minang et al., 2007). For FMUs, the forest legislation requires logging companies through their management plans to reduce forest degradation and enhance sustainable forests' management. For each year of operation, the forest administration validates the operational plan of logging companies containing species to be harvested and 
harvesting techniques. This is also the case with community forest entities in which through their simple management plans are required to enhance biodiversity conservation and sustainable forest management through afforestation, reforestation and conservation. Community forest entities need to demonstrate yearly with the approval of the forest administration, their ability to minimise risks on forest cover change and biodiversity conservation. In the two cases, implementation and monitoring are relevant. Thus, ensuring the strict implementation of the forest ecosystem management plan agreements both for logging concessions and community forest is a situation which is beneficial for REDD+ carbon effectiveness.

\section{Conclusion}

Cameroon is in the process of designing its national REDD+ strategy. However, based on research outcomes of the two forests' management regimes, it is too early to make conclusions on which of them better fits REDD+. In the context of the 2Es, studies have much swayed on equity in benefit sharing with both state and community management regimes producing poor results. On carbon effectiveness, research is limited on forest cover change in forests managed by the state through logging concessions and community forests. With so much REDD+ hinging on carbon measurement and accounting, it is urgent to have field based research on forests land use, actors, their activities and motivations, which are relevant for understanding the processes of leakage and permanence. More in-depth research with rigorous methods is needed to generate knowledge and information on forest cover change both in logging concessions and other state managed forests and community forests to better and positively influence and avoid premature conclusions by policy makers and practitioners in the REDD+ strategy in Cameroon.

However, there is urgent need to strengthen the governance of the forest revenue distribution systems and the monitoring of forest cover change, in case the present national REDD+ architecture hopes to build on existing forest governance structures.

\section{Acknowledgements}

The authors will like to thank the two anonymous reviewers and the editor for their comments which has greatly improved the quality of the paper. The paper has been produced as part of component 2 on research and knowledge gaps in the Congo Basin Forest and Climate Change Adaptation and Mitigation (COBAM) project, implemented by CIFOR and funded by the AfDB and CEEAC through the COMIFAC-PACEBCo program. The views expressed in this paper remain those of the authors and not of the donors or the affiliated organizations.

\section{References}

Agrawal, A., \& Angelsen, A. (2009). Using community forest management to achieve REDD+ goals. In A. Angelsen, M. Brockhaus, M. Kanninen, E. Sills, W. D. Sunderlin, \& S. Wertz-Kanounnikoff (Eds.), Realising REDD+: National strategy and policy options. Bogor, Indonesia: CIFOR.

Alemagi, D., \& Kozak, R. A. (2010). Illegal logging in Cameroon: Causes and the path forward. Forest Policy and Economics, 12, 554-561. http://dx.doi.org/10.1016/j.forpol.2010.07.008

Angelsen, A. (2008). Moving ahead with REDD: issues, options and implications. Bogor, Indonesia: Center for International Forestry Research (CIFOR).

Angelsen, A., \& Wertz-Kanounnikoff, S. (2008). What are the key design issues for REDD and the criteria for assessing options? In A. AGELSEN (Ed.), Moving ahead with REDD: Issues, options and implications. Bogor, Indonesia: CIFOR.

Angelsen, A., Brockhaus, M., Kanninen, M., Sills, E., Sunderlin, W. D., \& Wertz-Kanounnikoff, S. (2009). Realising REDD+: national strategy and policy options. Bogor, Indonesia: Center for International Forestry Research (CIFOR).

Angelsen, A., Brockhaus, M., Sunderlin, W. D., \& Verchot, L. V. (2012). Analysing REDD+: Challenges and Choices. Bogor, Indonesia: Center for International Forestry Research (CIFOR).

Asner, G. P. (2011). Painting the world REDD: addressing scientific barriers to monitoring emissions from $\begin{array}{llll}\text { tropical forests. Environmental Research Letters, } & 6,1002 .\end{array}$ http://dx.doi.org/10.1088/1748-9326/6/2/021002

Assembe, M. S. (2006a). Decentralized forest resources and access of minorities to environmental justice: an analysis of the case of the Baka in southern Cameroon. International Journal of Environmental Studies, 65, 681-689. http://dx.doi.org/10.1080/00207230600963825

Assembe, M. S. (2006b). Forestry income management and poverty reduction: empirical findings from Kongo, 
Cameroon. Development in Practice, 16, 68-73. http://dx.doi.org/10.1080/09614520500450867

Atmadja, S., \& Verchot, L. V. (2011). A review of the state of research, policies and strategies in addressing leakage from reducing emissions from deforestation and forest degradation (REDD+). Mitigation and Adaptation Strategies for Global Change, 17, 311-336. http://dx.doi.org/10.1007/s11027-011-9328-4

Awono, A., Somorin, O. A., Eba’a Atyi, R., \& Levang, P. (2013). Tenure and participation in local REDD+ projects: Insights from southern Cameroon. Environmental Science \& Policy. (In Press.) http://dx.doi.org/10.1016/j.envsci.2013.01.017

Begombe, P. (2003). The Decentralized Forestry Taxation System in Cameroon: Local Management and State Logic. Working Paper No. 10. Washington D.C: World Resource Institute.

Börner, J., Wunder, S., Wertz-Kanounnikoff, S., Tito, M. R., Pereira, L., \& Nascimento, N. (2010). Direct conservation payments in the Brazilian Amazon: Scope and equity implications. Ecological Economics, 69, 1272-1282. http://dx.doi.org/10.1016/j.ecolecon.2009.11.003

Brown, S., Burnham, M., Delaney, M., Powell, M., Vaca, R., \& Moreno, A. (2000). Issues and challenges for forest-based carbon-offset projects: A case study of the Noel Kempff climate action project in Bolivia. Mitigation and Adaptation Strategies for Global Change, 5, 99-121. http://dx.doi.org/10.1023/A:1009620903231

Cerutti, P. O., \& Tacconi, L. (2006). Forests, Illegality, and Livelihoods in Cameroon. Working Paper Bogor. Center for International Forestry Research (CIFOR).

Cerutti, P. O., Lescuyer, G., Assembe Mvondo, S., \& Tacconi, L. (2010). The challenges of redistributing forest-related monetary benefits to local governments: a decade of logging area fees in Cameroon. International Forestry Review, 12, 130-138. http://dx.doi.org/10.1505/ifor.12.2.130

Cerutti, P. O., Nasi, R., \& Tacconi, L. (2008). Sustainable Forest Management in Cameroon Needs More than Approved Forest Management Plans. Ecology and Society, 13(2), 36. Retrieved from http://www.ecologyandsociety.org/vol13/iss2/art36/

Chhatre, A., Lakhanpal, S., Larson, A. M., Nelson, F., Ojha, H., \& Rao, J. (2012). Social safeguards and co-benefits in REDD+: a review of the adjacent possible. Current Opinion in Environmental Sustainability, 4, 654-660. http://dx.doi.org/10.1016/j.cosust.2012.08.006

Chia, E. L., Somorin, O. A., Sonwa, D. J., \& Tiani, A. M. (2013). Local vulnerability, Forest communities and Forest-carbon conservation: case of southern Cameroon. International Journal of Biodiversity and Conservation, 5, 498-507.

Corbera, E., \& Schroeder, H. (2011). Governing and implementing REDD+. Environmental Science \& Policy, 14, 89-99. http://dx.doi.org/10.1016/j.envsci.2010.11.002

Corbera, E., Brown, K., \& Adger, W. N. (2007a). The Equity and Legitimacy of Markets for Ecosystem Services. Development and Change, 38, 587-613. http://dx.doi.org/10.1111/j.1467-7660.2007.00425.x

Corbera, E., Kosoy, N., \& Martínez Tuna, M. (2007b). Equity implications of marketing ecosystem services in protected areas and rural communities: Case studies from Meso-America. Global Environmental Change, 17, 365-380. http://dx.doi.org/10.1016/j.gloenvcha.2006.12.005

Djoufack, V., Fontaine, B., Martiny, N., \& Tsaléfac, M. (2012). Climatic and demographic determinants of vegetation cover in northern Cameroon. International Journal of Remote Sensing, 33, 6904-6926. http://dx.doi.org/10.1080/01431161.2012.693968

Ekoko, F. (1997). The Political Economy of the 1994 Cameroon Forest Law. Working Paper No.3. Yaoundé: CIFOR.

Ekoko, F. (2000). Balancing Politics, Economics and Conservation: The Case of the Cameroon Forestry Law Reform. Development and Change, 31, 131-154. http://dx.doi.org /10.1111/1467-7660.00149

Elkington, J. (1997). Cannibals with forks: the Triple Bottom Line of $21^{\text {st }}$ Century Business. Oxford: Capstone Publishing Ltd..

Epule, E. T., Peng, C., Lepage, L., \& Chen, Z. (2011). Forest loss triggers in Cameroon: A quantitative assessment using multiple linear regression approach. Journal of Geography and Geology, 3, 30-41. http://dx.doi.org/10.5539/jgg.v3n1p30

Epule, T.E., Peng, C., Lepage, L., \& Chen, Z. (2013). Policy options towards deforestation reduction in 
Cameroon: an analysis based on a systematic approach. Land use policy. http://dx.doi.org/10.1016/j.landusepol.2013.09.004.

Ezzine De Blas D., Ruiz-Pérez, M., \& Vermeulen, C. (2011). Management conflicts in Cameroonian community forests. Ecology and Society, 16(1), 8. Retrieved from http://www.ecologyandsociety.org/vol16/iss1/art8/

FAO. (2011). The State of Forests in the Amazon Basin, Congo Basin and Southeast Asia. A report prepared for the Summit of the Three Rainforest Basins, Brazzaville, Republic of Congo, 31 May-3 June, 2011. Rome: Food and Agriculture Organisation.

Füssel, H. M. (2007). Adaptation planning for climate change: concepts, assessment approaches, and key lessons. Sustainability Science, 2, 265-275. http://dx.doi.org /10.1007/s11625-007-0032-y

Gibson, L., Lee, T. M., Koh, L. P., Brook, B. W., Gardner, T. A., Barlow, J., ... Sodhi, N. S. (2011). Primary forests are irreplaceable for sustaining tropical biodiversity. Nature, 1. http://dx.doi.org /10.1038/nature10425

GOC. (1994). Law No. 94-01 of 20 January 1994 to Lay Down Forestry, Wildlife and Fisheries Regulations. Younde, Cameroon: Government of Cameroon.

GOC. (1995). Decree No. 95-531-PM of 23 August 1995 to Determine the Conditions for Implementation of Forestry Regulations. Yaounde,Cameroon: Goverment of Cameroon.

Grasso, M. (2007). A normative ethical framework in climate change. Climatic Change, 81, $223-246$. http://dx.doi.org /10.1007/s10584-006-9158-7

Gupta, A., Lövbrand, E., Turnhout, E., \& Vijge, M. J. (2012). In pursuit of carbon accountability: the politics of REDD+ measuring, reporting and verification systems. Current Opinion in Environmental Sustainability, 4, 726-731. http://dx.doi.org/10.1016/j.cosust.2012.10.004

Gupta, J. (2012). Glocal forest and REDD+ governance: win-win or lose-lose? Current Opinion in Environmental Sustainability, 4, 620-627. http://dx.doi.org/10.1016/j.cosust.2012.09.014

Herold, M., \& Skutsch, M. (2011). Monitoring, reporting and verification for national REDD + programmes: two proposals. Environmental Research Letters, 6, 014002. http://dx.doi.org/10.1088/1748-9326/6/1/014002

Ikeme, J. (2003). Equity, environmental justice and sustainability: incomplete approaches in climate change politics. Global Environmental Change, 13, 195-206. http://dx.doi.org/10.1016/S0959-3780(03)00047-5

Jagger, P., Lawlor, K., Brockhaus, M., Gebara, M. F., Sonwa, D. J., \& I. A. P, R. (2012). REDD+ safeguards in national policy discourse and pilot projects. Analysing REDD+: Challenges and choices. Bogor, Indonesia: Center for International Forestry Research (CIFOR).

Karsenty, A., Drigo, I. G., Piketty, M. G., \& Singer, B. (2008). Regulating industrial forest concessions in Central Africa and South America. Forest Ecology and Management, 256, 1498-1508. http://dx.doi.org/10.1016/j.foreco.2008.07.001

Klooster, D., \& Masera, O. (2000). Community forest management in Mexico: carbon mitigation and biodiversity conservation through rural development. Global Environmental Change, 10, $259-272$. http://dx.doi.org/10.1016/S0959-3780(00)00033-9

Larson, A. M., \& Petkova, E. (2011). An Introduction to Forest Governance, People and REDD+ in Latin America: Obstacles and Opportunities. Forests, 2, 86-111. http://dx.doi.org /10.3390/f2010086

Larson, A. M., Brockhaus, M., Sunderlin, W. D., Duchelle, A., Babon, A., Dokken, T., ... Huynh, T.-B. (2013). Land tenure and REDD+: The good, the bad and the ugly. Global Environmental Change, 23, 678-689. http://dx.doi.org/10.1016/j.gloenvcha.2013.02.014

Lasco, R., Pulhin, F., \& Sales, R. (2007). Analysis of leakage in carbon sequestration projects in forestry: a case study of upper magat watershed, Philippines. Mitigation and Adaptation Strategies for Global Change, 12, 1189-1211. http://dx.doi.org /10.1007/s11027-006-9059-0

Lawson, S., \& Macfaul, L. (2010) Illegal logging and related trade. Indicators of the Global Response (July, p. 132). London: Chatham House (The Royal Institute of International Affairs).

Lescuyer, G., Mbarga, H. N., \& Logo, P. B. (2008). Use and misuse of forest income by rural communities in Cameroon. Forests, Trees and Livelihoods, 18, 291-304. http://dx.doi.org /10.1080/14728028.2008.9752637

Maniatis, D., \& Mollicone, D. (2010). Options for sampling and stratification for national forest inventories to implement REDD+ under the UNFCCC. Carbon Balance and Management, 5, 1-14. 
http://dx.doi.org/10.1186/1750-0680-5-9

Mcdermott, M., Mahanty, S., \& Schreckenberg, K. (2012). Examining equity: A multidimensional framework for assessing equity in payments for ecosystem services. Environmental Science \& Policy. http://dx.doi.org/10.1016/j.envsci.2012.10.006

Medjibe, V. P., Putz, F. E., Starkey, M. P., Ndouna, A. A., \& Memiaghe, H. R. (2011). Impacts of selective logging on above-ground forest biomass in the Monts de Cristal in Gabon. Forest Ecology and Management, 262, 1799-1806. http://dx.doi.org/10.1016/j.foreco.2011.07.014

Mertens, B., Forni, E., \& Lambin, E. F. (2001). Prediction of the impact of logging activities on forest cover\&\#xa0;: A case-study in the East province of Cameroon. Journal of Environmental Management, 62, 21-36. http://dx.doi.org/10.1006/jema.2001.0417

Minang, P. A., Bressers, H. T. A., Skutsch, M. M., \& Mccall, M. K. (2007). National forest policy as a platform for biosphere carbon management: the case of community forestry in Cameroon. Environmental Science \& Policy, 10, 204-218. http://dx.doi.org/10.1016/j.envsci.2007.01.007

MINEPDED. (2012). Cameroon Readiness Preparation Proposal. Ministry of Environment, Nature Protection and Sustainable Development. World Bank Forests Carbon Partnership Facility.

MINFOF. (2009). Manual of the procedures for the attribution and norms for the management of community forests in Cameroon (Revised version). Yaounde, Cameroon: Ministry of Forestry and Wildlife.

Molua, E. L. (2012). Discourse on Climate Smart Agriculture for REDD+ Strategy in the Congo Basin. Journal of Sustainable Development, 5, 77-88. http://dx.doi.org/10.5539/jsd.v5n10p77

Morrison, K., Cerutti, P. O., Oyono, P. R., \& Steil, M. (2009). Broken Promises: Forest Revenue-Sharing in Cameroon. WRI Forest Note. Washington DC: World Resource Institute.

Murdiyarso, D., \& Skutsch, M. (2006). Community forest management as a carbon mitigation option: case studies. Bogor, Indonesia: Center for International Forestry Research (CIFOR).

Murdiyarso, D., Brockhaus, M., Sunderlin, W. D., \& Verchot, L. (2012). Some lessons learned from the first generation of REDD+ activities. Current Opinion in Environmental Sustainability, 4, 678-685. http://dx.doi.org/10.1016/j.cosust.2012.10.014

Murray, B. C., Mccarl, B. A., \& Lee, H.-C. (2004). Estimating Leakage from Forest Carbon Sequestration Programs. Land Economics, 80, 109-124. http://dx.doi.org/10.3368/le.80.1.109

Nebel, G., Quevedo, L., Bredahl Jacobsen, J., \& Helles, F. (2005). Development and economic significance of forest certification: the case of FSC in Bolivia. Forest Policy and Economics, 7, 175-186. http://dx.doi.org/10.1016/S1389-9341(03)00030-3

Oyono, P. R. (2004). The social and organisational roots of ecological uncertainties in Cameroon forest management decentralisation model. European Journal of Development Research, 16, 174-191. http://dx.doi.org/10.1080/09578810410001688798

Oyono, P. R. (2005). Profiling Local-Level Outcomes of Environmental Decentralizations: The Case of Cameroon's Forests in the Congo Basin. Journal of Environment and Development, 14, 317-337. http://dx.doi.org/10.1177/1070496505276552

Oyono, P. R., Cerutti, P. O., \& Morrison, K. (2009). Forest Taxation in Post-1994 Cameroon: Distributional Mechanisms And Emerging Links With Poverty Alleviation And Equity. Working Paper. Washington D.C World Resource Institute.

Oyono, P. R., Kouna, C., \& Mala, W. (2005). Benefits of forests in Cameroon. Global structure, issues involving access and decision-making hiccoughs. Forest Policy and Economics, 7, 357-368. http://dx.doi.org/10.1016/S1389-9341(03)00072-8

Oyono, P. R., Ribot, J. C., \& Larson, A. M. (2006). Green and Black Gold in Rural Cameroon: Natural Resources for Local Governance, Justice and Sustainability. Working Paper No. 22. Washington D.C: World Resource Institute.

Oyono, P. R., Ribot, J. C., Assembe, S., \& Logo, P. B. (2007). Improving Decentralised Forest Management in Cameroon: Options and Opportunities from Ten Years of Experience. Governance Brief, 33. CIFOR.

Palmer Fry, B. (2011). Community forest monitoring in REDD+: the ' $\mathrm{M}$ ' in MRV? Environmental Science \& Policy, 14, 181-187. http://dx.doi.org/10.1016/j.envsci.2010.12.004 
Pham, T. T., Brockhaus, M., Wong, G., Dung, L. N., Tjajadi, J. S., Loft, L., ... Assembe Mvondo, S. (2013). Approaches to benefit sharing: A preliminary comparative analysis of $13 \mathrm{REDD}+$ countries. Working Paper 108. Bogor, Indonesia: CIFOR.

Phelps, J., Webb, E. L., \& Agrawal, A. (2010). Does REDD+ Threaten to Recentralize Forest Governance? Science, 328, 312-313. http://dx.doi.org /10.1126/science.1187774

Putz, F. E., Sist, P., Fredericksen, T., \& Dykstra, D. (2008). Reduced-impact logging: Challenges and $\begin{array}{lllll}\text { opportunities. Forest Ecology and Management, 256, 1427-1433. } & \text {. }\end{array}$ http://dx.doi.org/10.1016/j.foreco.2008.03.036

Putz, F. E., Zuidema, P. A., Synnott, T., Peña-Claros, M., Pinard, M. A., Sheil, D., ... Zagt, R. (2012). Sustaining conservation values in selectively logged tropical forests: the attained and the attainable. Conservation Letters, 5, 296-303. http://dx.doi.org/10.1111/j.1755-263X.2012.00242

Reboredo F. (2013a) Illegal wood in Europe: a review. International Forestry Review, 15, 218-229. http://dx.doi.org/10.1505/146554813806948512

Reboredo F. (2013b) Socio-economic, environmental and governance impacts of illegal logging. Environment Systems \& Decision, 33, 295-304. http://dx.doi.org 10.1007/s10669-013-9444-7

Richards, M., \& Panfil, S. N. (2011). Towards Cost-Effective Social Impact Assessment of REDD+ Projects: Meeting the Challenge of Multiple Benefit Standards. International Forestry Review, 13, 1-12.http://dx.doi.org/10.1505/ifor.5.3.282.19153

Richards, M., Wells, A., Del Gatto, F., Contreras-Hermosilla, A., \& Pommier, D. (2003). Impacts of illegality and barriers to legality: a diagnostic analysis of illegal logging in Honduras and Nicaragua. International Forestry Review, 5, 282-292. http://dx.doi.org/10.1505/ifor.5.3.282.19153

Somorin, O. A., Visseren-Hamakers, I. J., Arts, B., Sonwa, D. J., \& Tiani, A.-M. (2013). REDD+ policy strategy in Cameroon: Actors, institutions and governance. Environmental Science \& Policy. (In Press.) http://dx.doi.org/10.1016/j.envsci.2013.02.004

Tacconi, L. (2007). Decentralization, forests and livelihoods: Theory and narrative. Global Environmental Change, 17, 338-348. http://dx.doi.org/10.1016/j.gloenvcha.2007.01.002

Tol, R. S. J. (2001). Equitable cost-benefit analysis of climate change policies. Ecological Economics, 36, 71-85. http://dx.doi.org/10.1016/S0921-8009(00)00204-4

Vatn, A., Barton, D. N., Lindhjem, H., Movik, S., Ring, I., \& Santos, R. (2011). Can markets protect biodiversity? An evaluation of different financial mechanisms Noragric report No. 60. NORAGRIC.

Visseren-Hamakers, I. J., Mcdermott, C., Vijge, M. J., \& Cashore, B. (2012). Trade-offs, co-benefits and safeguards: current debates on the breadth of REDD+. Current Opinion in Environmental Sustainability, 4, 646-653. http://dx.doi.org/10.1016/j.cosust.2012.10.005

WRI. (2011). Interactive Forest Atlas of Cameroon, (version 3.0). Washington DC: World Resource Institute (WRI). Retrieved from http://www.wri.org/publication/interactive-forestry-atlas-cameroon-version-3-0

\section{Copyrights}

Copyright for this article is retained by the author(s), with first publication rights granted to the journal.

This is an open-access article distributed under the terms and conditions of the Creative Commons Attribution license (http://creativecommons.org/licenses/by/3.0/). 